\title{
KAJIAN KONDISI ATMOSFER SAAT KEJADIAN HUJAN EKSTREM DI PADANG SUMATERA BARAT (STUDI KASUS TANGGAL 14 FEBRUARI 2018)
}

\author{
Rifky Hadiansyah ${ }^{1}$, Ardian L Indranata ${ }^{2}$, Andreas K Silitonga ${ }^{3}$, Paulus Agus Winarso ${ }^{4}$ \\ 1,2,3 Program Studi Klimatologi, Sekolah Tinggi Meteorologi Klimatologi dan Geofisika, \\ Jl. Perhubungan I No.5 Pondok Betung, Pondok Aren, Tangerang Selatan \\ 4 Sekolah Tinggi Meteorologi Klimatologi dan Geofisika, \\ Jl. Perhubungan I No.5 Pondok Betung, Pondok Aren, Tangerang Selatan \\ Email : rifkyhadiansyh@gmail.com
}

\begin{abstract}
Padang's West Sumatra region has an equatorial rain pattern, where every year there are two peaks of rain. On February 14, 2018, there has been extreme rain in the Padang area, West Sumatra reaching $193 \mathrm{~mm} /$ day. In this extreme rain study using ECMWF reanalysis data, HIMAWARI -8 satellite data, and observation data on the Minangkabau Meteorological Station, Padang. The data is processed using tables, and images then analyzed descriptively. Based on the results of the analysis, it was found that the extreme rainfall occurring in the Padang region of West Sumatra was due to the pattern of closed angina seen around the area around West Sumatra, the highest humidity values were wet to $200 \mathrm{mb}$, cloud cover patterns that support extreme rainfall, and is supported by divergence and vertical velocity as well as unstable air conditions in the West Sumatra region and beyond. The lowest cloud top temperature reaches $-74.5^{\circ} \mathrm{C}$, it is indicated that the clouds formed at the time of the incident are convective clouds that are multi-cell.
\end{abstract}

Keywords: Extreme Weather, Extreme Rain, Padang

\begin{abstract}
Abstrak: Wilayah Sumatera Barat tepatnya Padang memiliki pola hujan ekuatorial, dimana setiap tahun terdapat dua puncak hujan. Pada tanggal 14 Februari 2018, telah terjadi hujan ekstrem di wilayah Padang, Sumatera Barat mencapai $193 \mathrm{~mm} / \mathrm{hari}$. Dalam penelitian hujan ekstrem ini menggunakan data reanalysis ECMWF, data satelit HIMAWARI -8, serta data observasi permukaan Stasiun Meteorologi Minangkabau, padang. Data tersebut diolah dengan menggunakan tabel, dan gambar kemudian dianalisa secara deskriptif. Berdasarkan hasil analisis didapatkan bahwa kejadian hujan ekstrem yang terjadi di wilayah Padang, Sumatera Barat tersebut dikarenakan adanya pola angin tertutup yang terlihat di sekitar wilayah sekitar Sumatera Barat, nilai kelembaban relatif tinggi yakni basah hingga lapisan $200 \mathrm{mb}$, pola tutupan awan yang mendukung untuk untuk terjadinya hujan ekstrem, dan didukung oleh divergensi dan kecepatan vertikal juga kondisi udara yang labil di wilayah Sumatera Barat dan sekitarnya. Suhu puncak awan terendah mencapai $-74,5^{\circ} \mathrm{C}$, diindikasikan bahwa awan-awan yang terbentuk pada saat kejadian adalah awan konvektif yang bersifat multi sel.
\end{abstract}

Kata kunci: Cuaca Ekstrem, Hujan Ekstrem, Padang

\section{PENDAhULUAN}

Cuaca adalah keadaan udara atau atmosfer di suatu tempat dan pada waktu tertentu, contohnya hujan, Suhu, Tekanan Udara, Angin, Awan, Kelembaban Udara, Radiasi, Jarak Pandang atau Visibility (Zakir, 2006). Cuaca bisa terjadi di daerah mana saja terutama di bumi yang secara tidak langsung memiliki peran penting dalam aktifitas manusia. Hujan merupakan salah satu dari unsur cuaca yang sering terjadi di wilayah tropis terutama di 
Indonesia, dimana hujan dengan intensitas sangat lebat atau sering disebut hujan ekstrem dapat memberikan dampak bagi kehidupan manusia, salah satu contohnya ialah banjir.

Ditinjau dari faktor meteorologi, banjir umumnya disebabkan karena terjadinya hujan dengan intensitas lebat hingga sangat lebat dan durasi yang lama. Penyebab terjadinya hujan dengan intensitas lebat hingga sangat lebat tersebut masih sangat jarang disebutkan sehingga perlu untuk dikaji lebih lanjut. (BMKG, 2010) menyebutkan bahwa bencana alam merupakan rangkaian peristiwa yang mengancam dan mengganggu kehidupan masyarakat yang diakibatkan oleh cuaca ekstrem dengan salah satu kategori cuaca ekstrem adalah hujan lebat yaitu hujan dengan intensitas paling rendah $100 \mathrm{~mm} / \mathrm{hari}$ atau $20 \mathrm{~mm} / \mathrm{jam}$. Fenomena hujan lebat hingga sangat lebat sering mengakibatkan banjir pada sejumlah wilayah di Indonesia. salah satunya seperti yang terjadi di Kota Padang

Menurut Republika (2018) terdapat beberapa kawasan yang tergenang oleh banjir seperti kawasan Pegambiran Arai Pinang, Alang Lawas, By Pass, dan Kecamatan Lubuk Begalung. Banjir tersebut merupakan akibat dari hujan lebat yang turun selama 5 jam pada tanggal 14 Febuari 2018 mulai dari sore hari hingga malam hari. Banjir tersebut mengakibatkan air menggenangi pemukiman warga hingga setinggi $50 \mathrm{~cm}$ dibeberapa titik. Kondisi ini tentu saja mengakibatkan terganggunya aktivitas warga serta menimbulkan kerugian harta benda dan merusak tatanan ekosistem alam.

Pada tanggal 14 Febuari 2018 terjadi hujan dengan intensitas $193 \mathrm{~mm}$ di Stasiun Meteorologi Bandara Internasional Minangkabau. Menurut KEP.009 Tahun 2010 tentang "Prosedur Standar Operasional Pelaksana Peringatan Dini, Pelaporan, dan Diseminasi Informasi Cuaca Ekstrim", hujan yang terjadi pada tanggal tersebut dikategorikan sebagai hujan sangat lebat yang termasuk dalam cuaca ekstrim. Hujan tanggal 14 Febuari 2018 merupakan intensitas tertinggi di awal tahun 2018. Hujan dengan intensitas seperti ini mampu mengurangi jarak pandang (visibility), akibatnya proses take off dan landing menjadi terganggu.

Dari kejadian banjir pada tanggal 14 Febuari 2018 yang menyebabkan banjir di kota Padang perlu di lakukan sebuuah penelitian untuk megetahui penyebab banjir. Penelitian dilakukan dengan melihat fenomena cuaca yang terjadi pada saat kejadian baik dalam skala lokal maupun skala regional. Melihat tumbuh dan luruhnya awan di sekitar Kota Padang dengan menggunakan citra satelit Himawari-8 agar dapat mendeteksi potensi sebaran awan awan konfektif, Menganalisis RH (Relative Humidiy) untuk melihat potensi hujan, mengidentifikasi pola persebaran angin serta divergensi dan kecepatan vertikal yang menyebabkan terjadinya hujan ekstrem di Padang pada tanggal 14 Febuari 2018. 


\section{METODE PENELITIAN}

\subsection{Lokasi Penelitian}

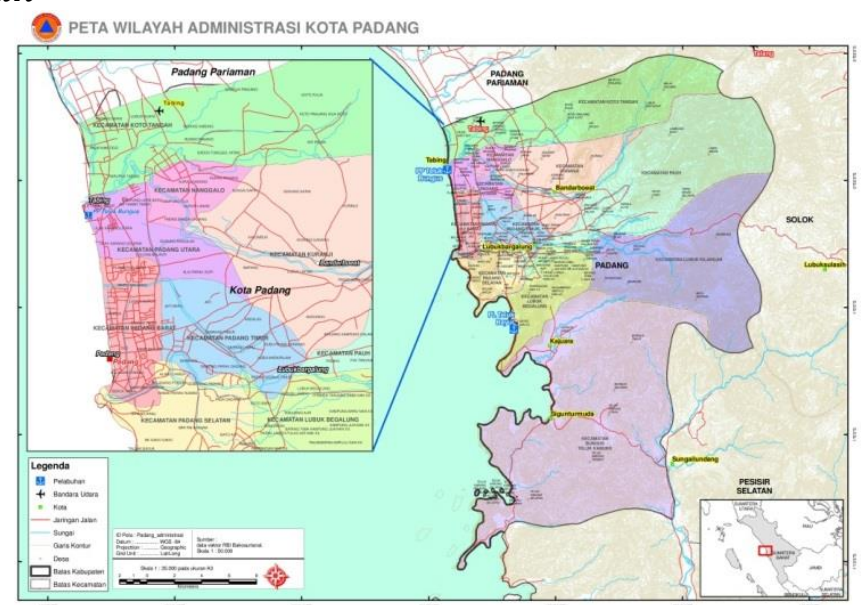

Gambar 4. Lokasi Penelitian (Sumber: BNPB, 2009)

Lokasi penelitian adalah Kota Padang dengan koordinat $00^{\circ} 44^{\prime} \mathrm{LS}-01^{\circ} 08^{\prime}$ LS dan $100^{\circ}$ $05^{\prime} \mathrm{BT}-100^{\circ} 34^{\prime} \mathrm{BT}$

\subsection{Data}

Penelitian ini menggunakan data meteorologi yaitu data curah hujan harian tanggal 14 februari 2018 yang diambil dari observasi Stasiun Meteorologi Minangkabau. Data ini digunakan sebagai indicator bahwa terjadi hujan lebat di Kota Padang. Selanjutnya data angin komponen u dan v didapat dari laman ECMWF http://apps.ecmwf.int/datasets/data/interim-fulldaily/. Data ini digunakan untuk melihat pola streamline, sehingga dapat diketahui daerah pembentukan awan.

Data yang selanjutnya adalah data citra satelit cuaca Himawari-8 kanal IR dan VIS pada tanggal 14 februari 2018. Data tersebut diperoleh dari Sub Bidang Pusat Pengelolaan Citra Satelit BMKG. Data tersebut digunakan untuk mengetahui suhu puncak awan, tutupan awan dan keadaan stabilitas atmosfer di wilayah Padang.

\subsection{Metode}

Data komponen angin $\mathrm{u}$ dan $\mathrm{v}$ pada ketinggian 10 meter diolah dengan menggunakan perangkat lunak Grid Analysis and Display System (GrADS) untuk mendapatkan tampilan streamline dan kelembaban secara spasial di wilayah Padang.

Selanjutnya pengolahan data Himawari-8 menggunakan perangkat lunak dari pengolahan citra satelit Himawari-8 dengan menggunakan aplikasi Satellite Animation dan Interaktif Diagnosis (SATAID) yaitu tenik menampilkan citra satelit sebagai indentifikasi awan dan teknik pemanfaatan data Numerical Weather Prediction (NWP) sebagai analisis unsur-unsur cuaca (Fadholi, 2013). Untuk mengetahui pola pertumbuhan awan, dilihat dengan menggunakan analisis time series suhu puncak awan. Selain itu, dengan memanfaatkan teknik data Numerical Weather Prediction (NWP) didapatkan indeks kestabilan atmosfir. Indeks tersebut nantinya dianalisis berdasarkan kriteria setiap indeks. Sehingga diketahui bahwa keadaan atmosfir di wilayah Padang, stabil, tidak stabil, atau normal yang mengidikasikan kuat atau lemahnya konveksi yang terjadi. 
Tabel 1. Interval Indeks Stabilitas Atmosfer untuk Wilayah Tropis (Budiarti et al., 2012)

\begin{tabular}{llll}
\hline Indeks & Lemah & Moderat & Kuat \\
\hline TT Index & $<42$ & $42-46$ & $>46$ \\
K Index & $<29$ & $29-37$ & $>37$ \\
SWEAT & $<135$ & $135-239$ & $>239$ \\
CAPE & $<1000$ & $1000-2500$ & $>2500$ \\
\hline
\end{tabular}

\section{HASIL DAN PEMBAHASAN}

\subsection{Citra Satelit Himawari-8}

\subsubsection{Time Series Suhu Puncak Awan}

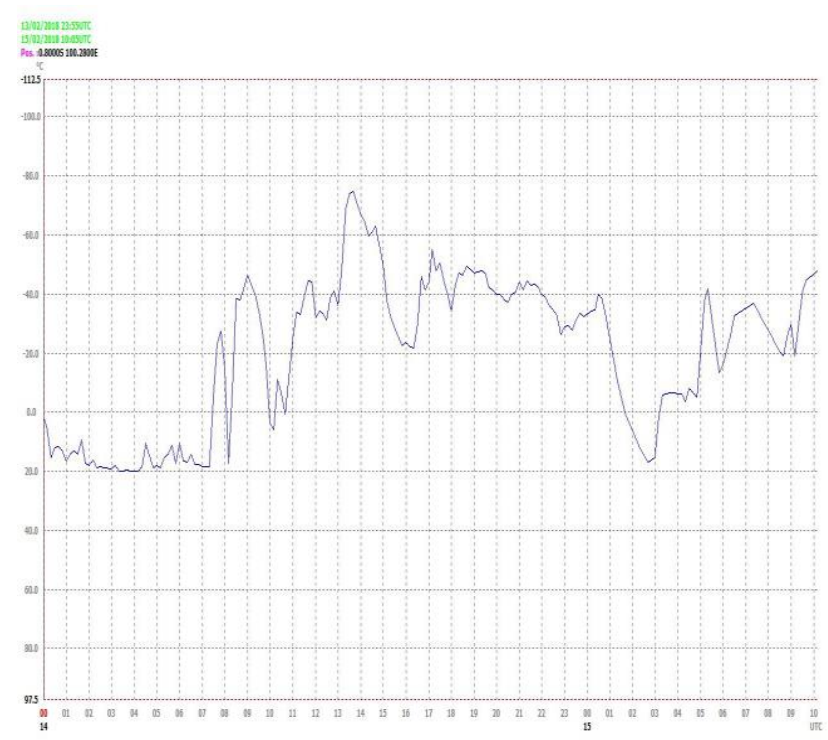

Gambar 5. Time Series Profil Suhu Puncak Awan

Berdasarkan analisis time series pertumbuhan awan, terlihat bahwa telah terjadi pertumbuhan awan konvektif sekitar pukul 10.40 UTC dengan ditandai mulai naiknya suhu puncak awan di Kota Padang. Terdapat satu puncak pada time series yang mengindikasikan di titik tersebut terjadi pertumbuhan awan multisel. Aktivitas konvektif terus berlangsung hingga sekitar pukul 13.35 UTC dan suhu puncak awan mencapai $-74.5{ }^{\circ} \mathrm{C}$. Setelah itu awan mengalami fase disipasi sekitar pukul 15.05 UTC dengan ditandai terjadinya kenaikan suhu puncak awan (menghangat) hal ini mengidikasikan awan mulai meluruh dan turun ke lapisan yang lebih rendah. 


\subsubsection{Pertumbuhan Awan}

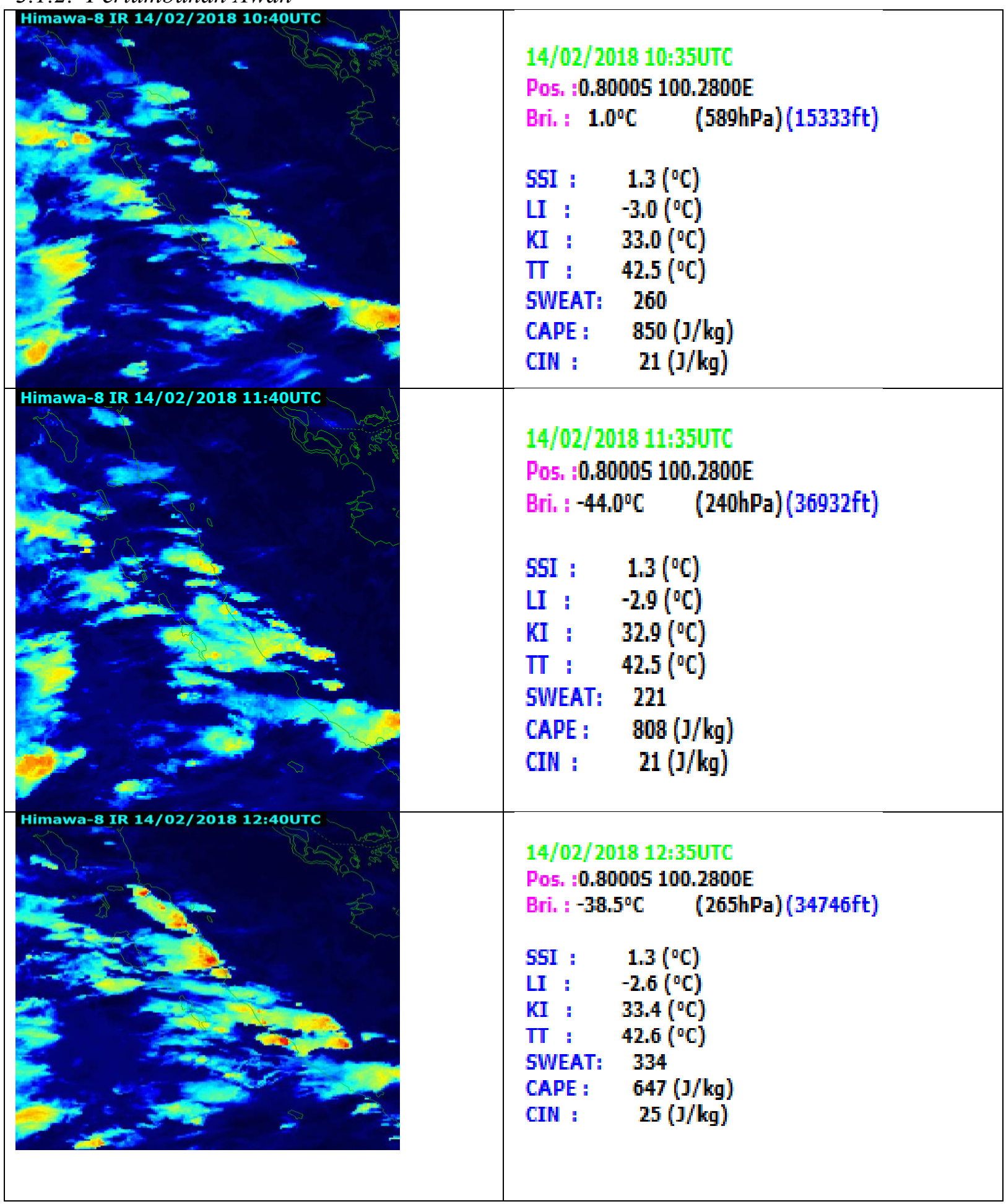

Gambar 6. Mulainya Pertumbuhan Awan

Pada fase tumbuh, dimulai pada pukul 10.35 UTC yang diawali dengan suhu puncak awan sebesar $1,0{ }^{\circ} \mathrm{C}$. Hal ini menandakan awan - awan masih berada di lapisan bawah (hangat). Sedangkan dari data stabilitas udara nilai CAPE sebesar $850 \mathrm{~J} / \mathrm{kg}$ dan nilai SWEAT 260 termasuk dalam kategori konveksi sedang. Untuk nilai TT Indeks $42,5{ }^{\circ} \mathrm{C}$ dan $\mathrm{K}$ Indeks 
sebesar $33,0{ }^{\circ} \mathrm{C}$ yang berarti termasuk dalam kategori konveksi sedang. Dari data indeks stabilitas atmosfer tersebut didapatkan bahwa awan - awan konvektif akan berpotensi tumbuh di Kota Padang. Nilai -nilai indeks labilitas atmosfer pada kota padang terus meningkat secara kontinu sampai pukul 12.35 UTC.

\subsubsection{Awan Matang}

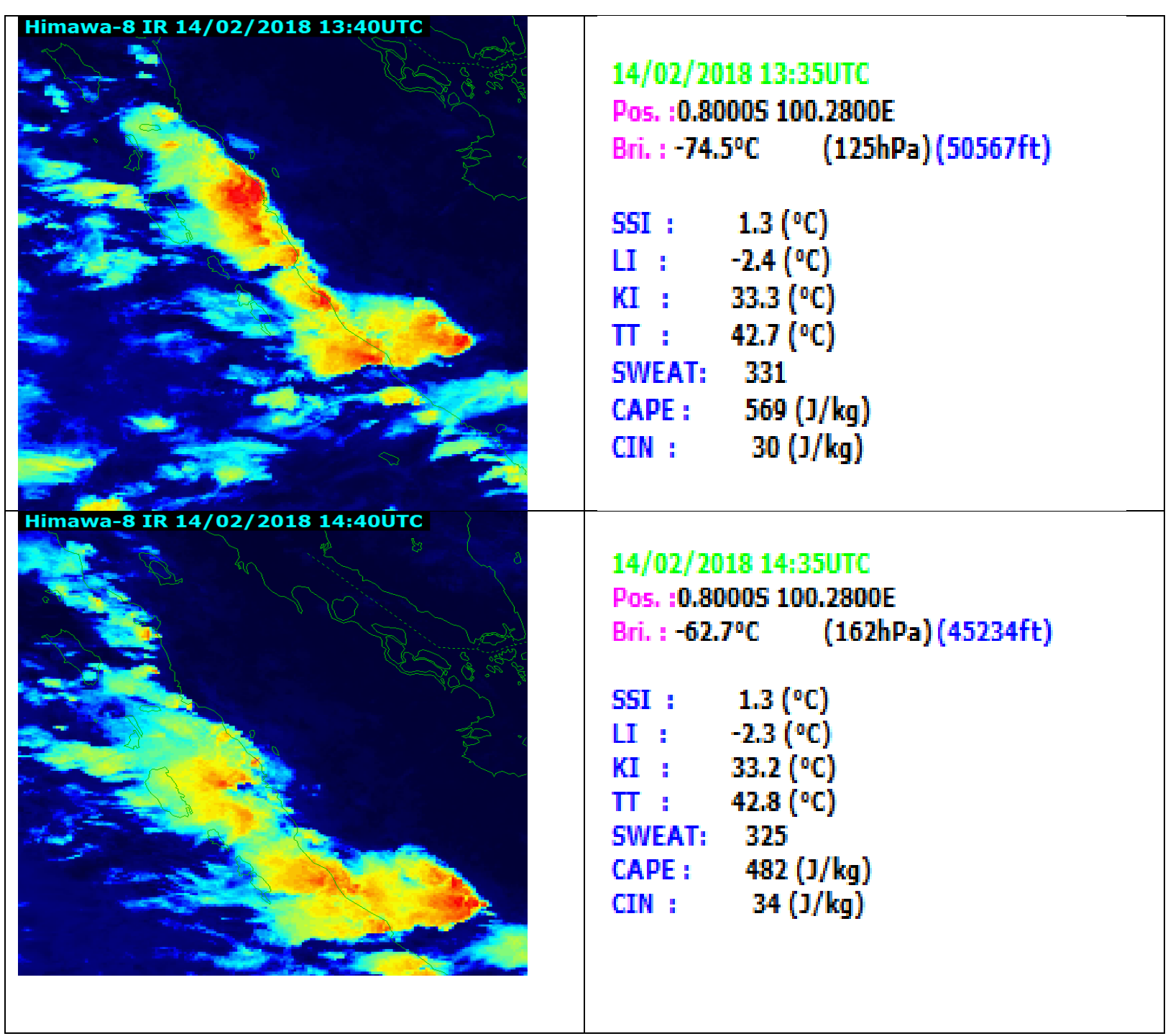

Gambar 7. Fase Matang

Berdasarkan kanal infrared pada satelit himawari-8 terlihat gugusan awan berwarna orange hingga merah di sekitar daerah Padang. Warna merah tersebut menunjukkan suhu puncak awan sangat dingin dan kandungan uap air bahkan es yang banyak karena berada di lapisan atas. Pada tanggal 9 September 2017 telihat adanya awan konvektif multisel antara lain terjadi pada pukul: 13.35 UTC dan 14.35 UTC dengan suhu sekitar $-74.5^{\circ} \mathrm{C}$. Awan ini terindikasi sebagai awan cumulonimbus yang dapat menghasilkan curah hujan dengan intensitas yang sedang hingga lebat dan downdraft yang kuat. Sedangkan dari data stabilitas udara nilai CAPE sebesar $569 \mathrm{~J} / \mathrm{kg}$ dan nilai SWEAT 331 termasuk dalam kategori konveksi kuat. Untuk nilai TT Indeks $42,7{ }^{\circ} \mathrm{C}$ dan $\mathrm{K}$ Indeks sebesar $33,2{ }^{\circ} \mathrm{C}$ yang berarti termasuk dalam kategori 
konveksi sedang. Dari data indeks stabilitas atmosfer tersebut didapatkan bahwa awan - awan konvektif telahtumbuh dengan matang di Kota Padang.

\subsubsection{Fase Disipasi/Luruh}

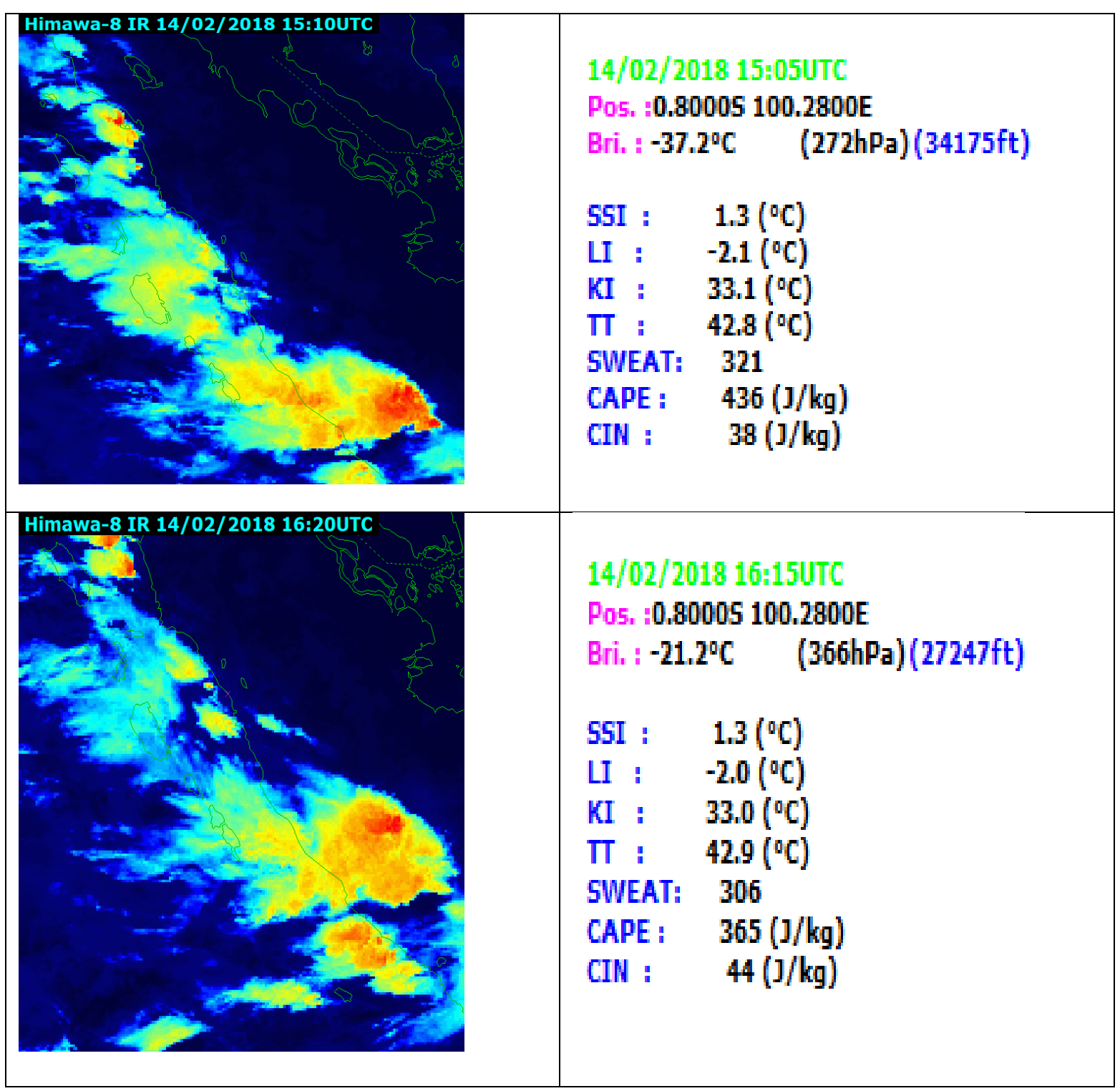




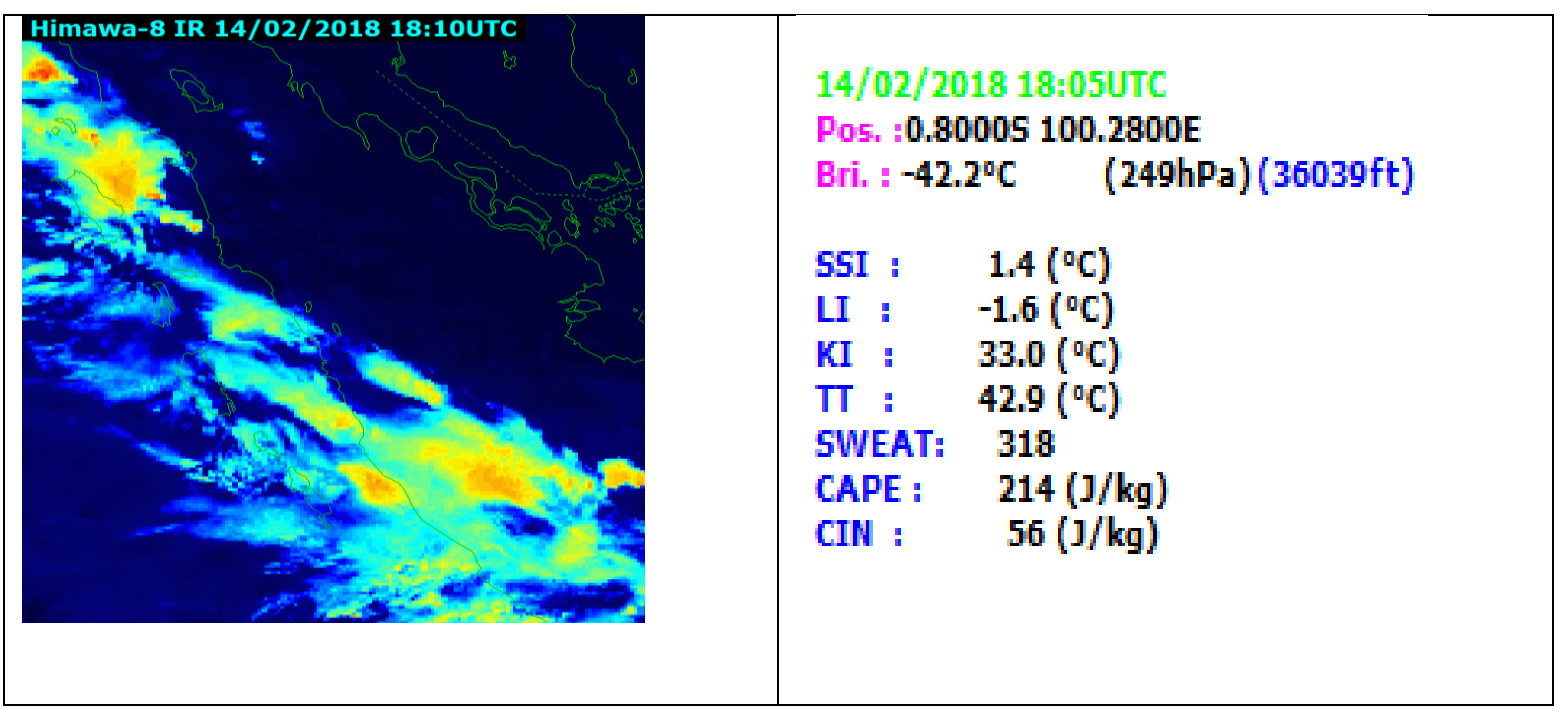

\section{Gambar 8. Fase Disipasi/Luruh}

Berdasarkan kanal infrared pada satelit himawari-8 pada pukul 18.05 UTC di daerah Padang sudah tidak terlihat gugusan awan - awan konvektif. Hal itu dapat dilihat suhu puncak awan di titik tersebut sebesar $-42.2^{\circ} \mathrm{C}$ yang mengindikasikan hanya terdapat awan - awan rendah (cumulus). Sedangkan dari data stabilitas udara nilai CAPE sebesar $214 \mathrm{~J} / \mathrm{kg}$ dan nilai SWEAT 318 termasuk dalam kategori konveksi lemah. Untuk nilai TT Indeks $42,9{ }^{\circ} \mathrm{C}$ dan $\mathrm{K}$ Indeks sebesar $33,0{ }^{\circ} \mathrm{C}$ yang berarti termasuk dalam kategori konveksi sedang. Dari data indeks stabilitas atmosfer tersebut didapatkan bahwa awan - awan konvektif akan mulai luruh di Kota Padang.

\subsection{Analisis $\mathrm{RH}$}

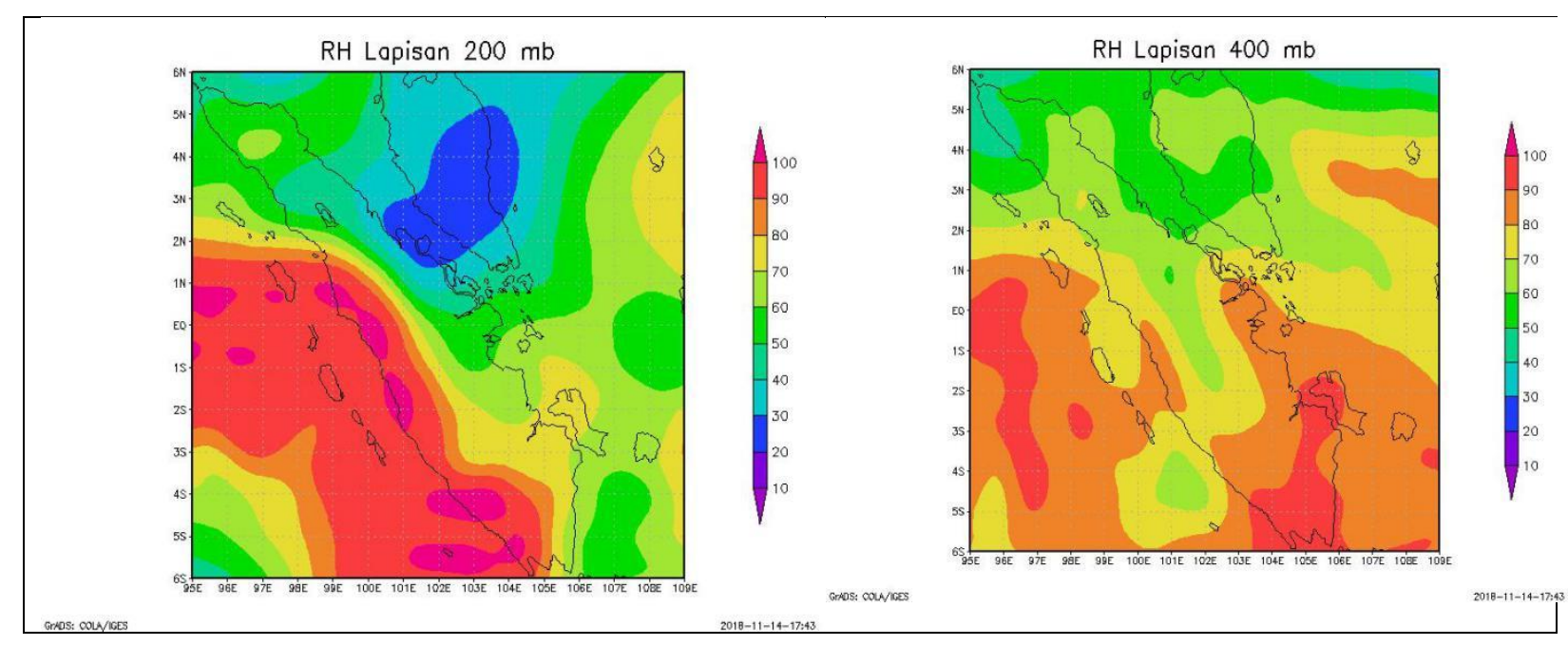




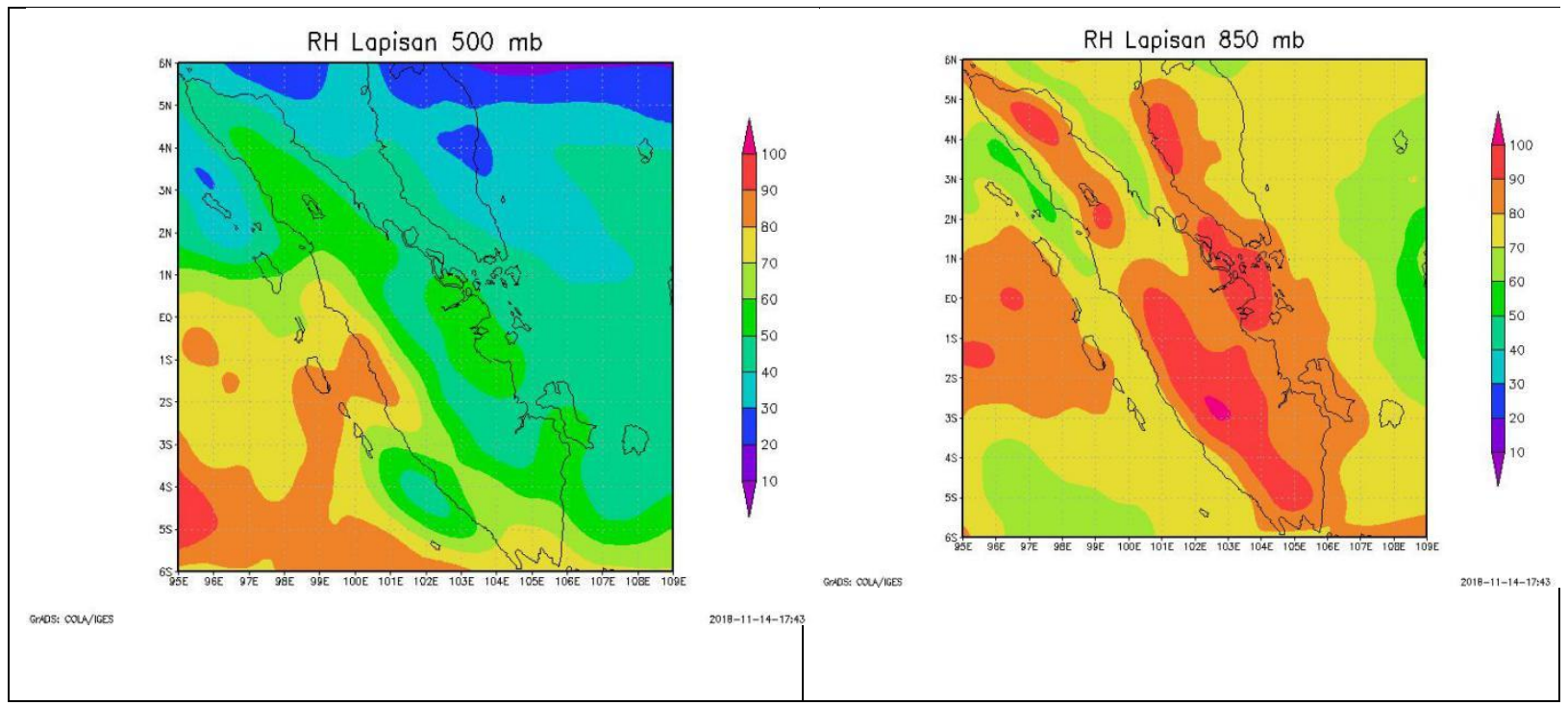

Gambar 9. Profil RH Pulau Sumatera di Lapisan $200 \mathrm{mb}$ (a) $400 \mathrm{mb}$ (b) $500 \mathrm{mb}$ (c) dan 850 $\mathrm{mb}(\mathrm{d})$

Berdasarkan nila RH perlapisan terlihat bahwa kelembaban udara di lapisan $850 \mathrm{mb}$ hingga lapisan $200 \mathrm{mb}$ terlihat antara kisaran 80 hingga 100\% yang menandakan bahwa pada dasarnya massa udara yang ada di padang terlihat basah sehingga menandakan bahwa terdapat pertumbuhan awan konvektif yang cukup besar di wilayah Padang.

\subsection{Analisa Gradien Angin}

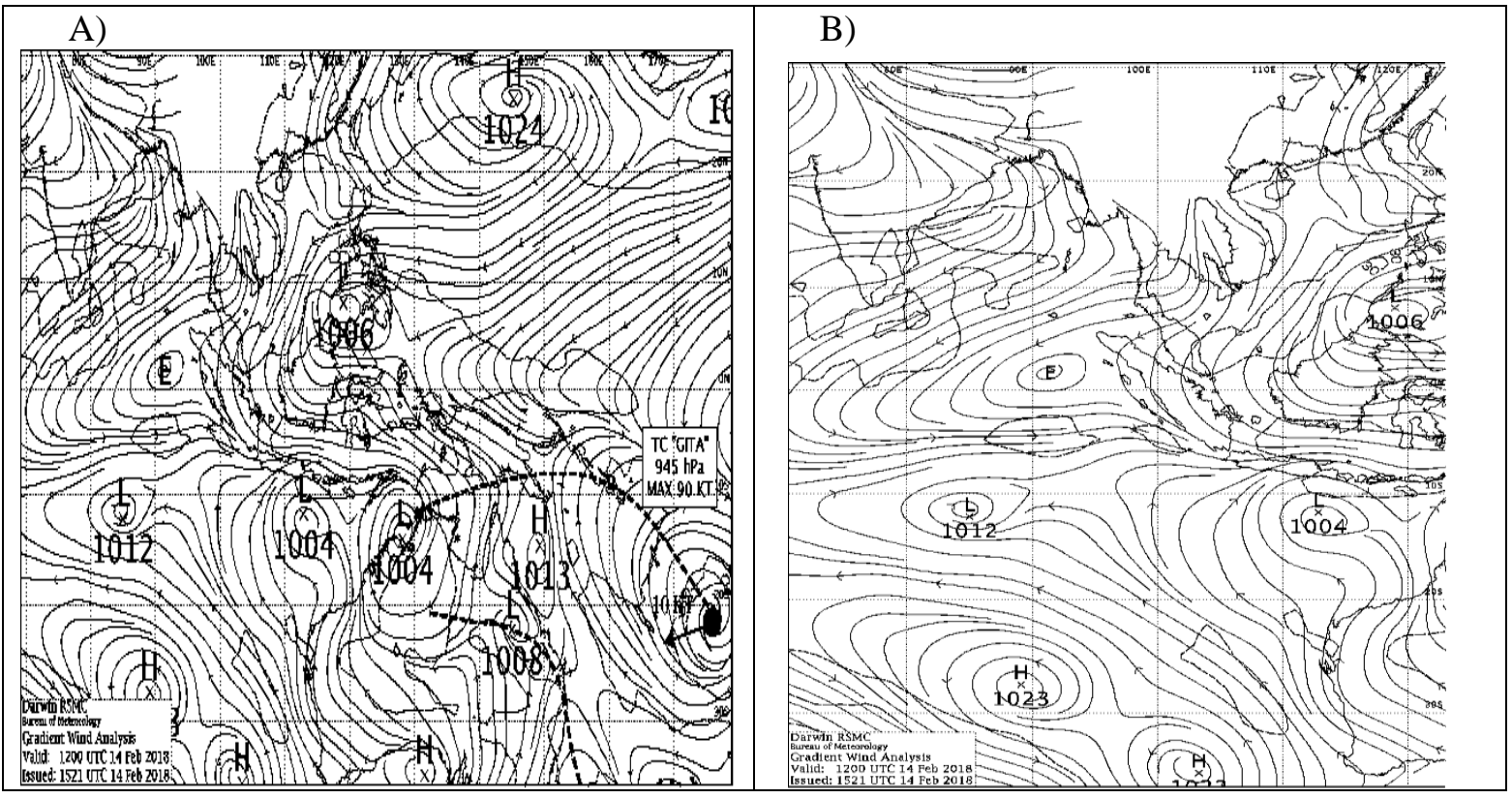

Gambar 10. Gradien angin wilayah Indonesia (a) Gradien angin wilayah Pulau Sumatera (b)

(Sumber BOM, 2018) 
Berdasarkan peta analisa pola angin tanggal 14 Febuari 2018 pukul 12.00 UTC (19.00 WIB) terlihat beberapa adanya pusat tekanan rendah (Low Pressure), salah satunya di Samudera Hindia dekat perairan barat Sumatera. Selain itu terapat pula pusaran Eddy di sebelah barat Sumatera equator. Pertemuan arus Eddy dan pusat tekanan rendah tersebut mengakibatkan adanya pertemuan dua massa udara yang dibelokkan menuju ke arah Sumatera sehingga dapat menyebabkan pertumbuhan - awan awan konvektif dan berpotensi hujan di daerah sekitarnya, termasuk Sumatera Barat. Selain itu terlihat adanya siklon tropis GITA yang berpusat di sebelah utara New Zealand. Siklon aktif tersebut berpengaruh pada terbentuknya pola pola tekanan rendah yang berada di sebelah selatan hingga barat indonesia, atau sekitar $10^{\circ} \mathrm{LS}$.

\subsection{Analisa Suhu Muka Laut}

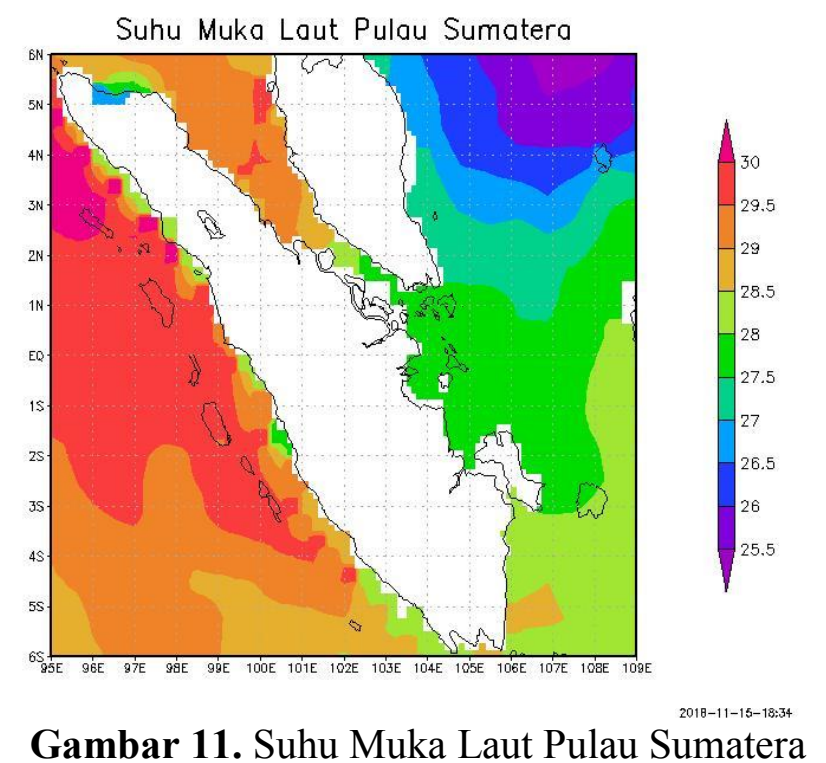

Suhu muka laut harian di perairan barat Sumatera pada tanggal 14 Febuari 2018 berkisar antara 28 hingga $30{ }^{\circ} \mathrm{C}$. Suhu muka laut yang hangat $\left(>27,0^{\circ} \mathrm{C}\right)$ mengindikasikan bahwa kandungan uap air yang terkandung di perairan tersebut cukup banyak, sehingga potensi pembentukan awan - awan konvektif sangat besar. 


\subsection{Analisa Kecepatan Vertikal}

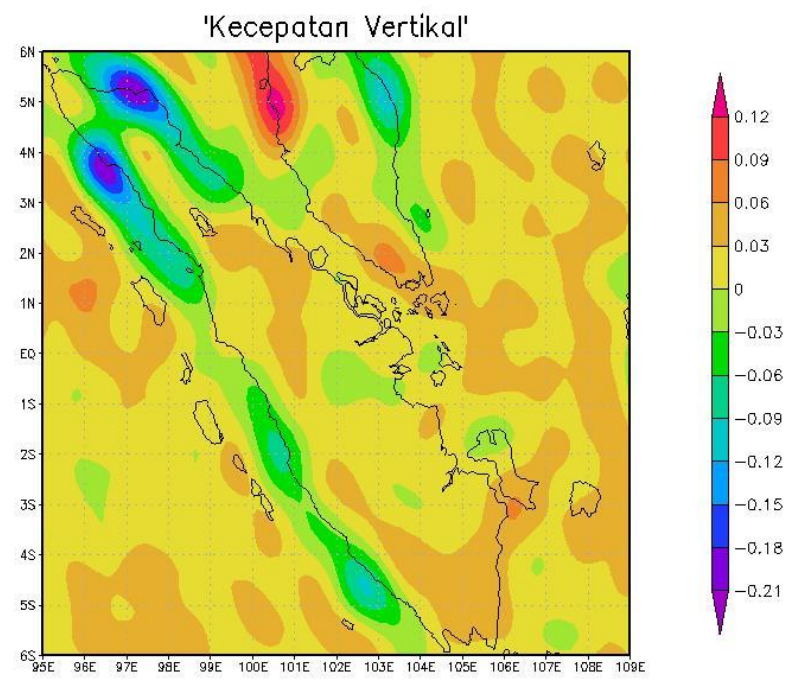

GrADS: COLA/IGES

Gambar 9. Kecepatan Vertikan Kota Padang

Dilihat dari kecepatan vertikal terlihat kecepatan vertikal yang terjadi di wilayah Kota Padang berkisar antara 0 hingga $-0.06^{\circ} \mathrm{C}$ yang menandakan adanya proses pertumbuhan awan konvektif yang cukup matang

\section{KESIMPULAN}

Berdasarkan analisis diatas dapat disimpulkan bahwa kejadian banjir di Kota Padang yang terjadi tanggal 14 Februari umumnya lebih disebabkan oleh curah hujan ekstrim yang jauh diatas rata ratanya akibat adanya belokan massa udara yang disebabkan oleh adanya pertemuan arus Eddy dan pusat tekanan rendah yang berada di Samudera Hindia. Peningkatan suhu muka laut juga dapat meningkatkan potensi penambahan hujan yang terjadi. Fenomena ini mendukung pertumbuhan awan yang berpotensi menyebabkan terjadinya hujan dengan intensitas sedang hingga lebat dan dapat berdampak pada terjadinya banjir.

\section{SARAN}

Dalam penelitian ini diperlukan adanya penelitian lebih lanjut untuk mengamati kondisi atmosfer dengan memanfaatkan data udara atas dan radar cuaca yang berguna dalam pembuatan peringatan dini adanya fenomena cuaca ekstrim.

\section{DAFTAR PUSTAKA}

BMKG. (2010). Prosedur Standar Operasional Pelaksanaan Peringatan Dini, Pelaporan, dan Desiminasi Informasi Cuaca Ekstrim. Indonesia,KEP.009.

Fadholi, A. (2013) . Pengolahan Data Citra Satelit MTSAT Menggunakan Aplikasi Sataid (Sattelite Animations And Interactive Diagnosis). Jurnal Informatika dan Komputasi STMIK Indonesia Jakarta. Vol.7 No.1.

Zakir, A. (2006). Training Workshop Meteorologi, Klimatologi dan Geofisika untuk Media Jasa dan Pengguna Jasa. BMKG,Bogor. 
http://www.bom.gov.au/products/IDX0514.shtml diakses pada tanggal 1 November 2018 http://geospasial.bnpb.go.id/ diakses pada tanggal 1 November 2018 https://www.republika.co.id/berita/nasional/daerah/17/09/09/ow0bhx-diguyur-hujan-deras-5jam-padang-dikepung-banjir diakses pada tanggal 1 November 2018 